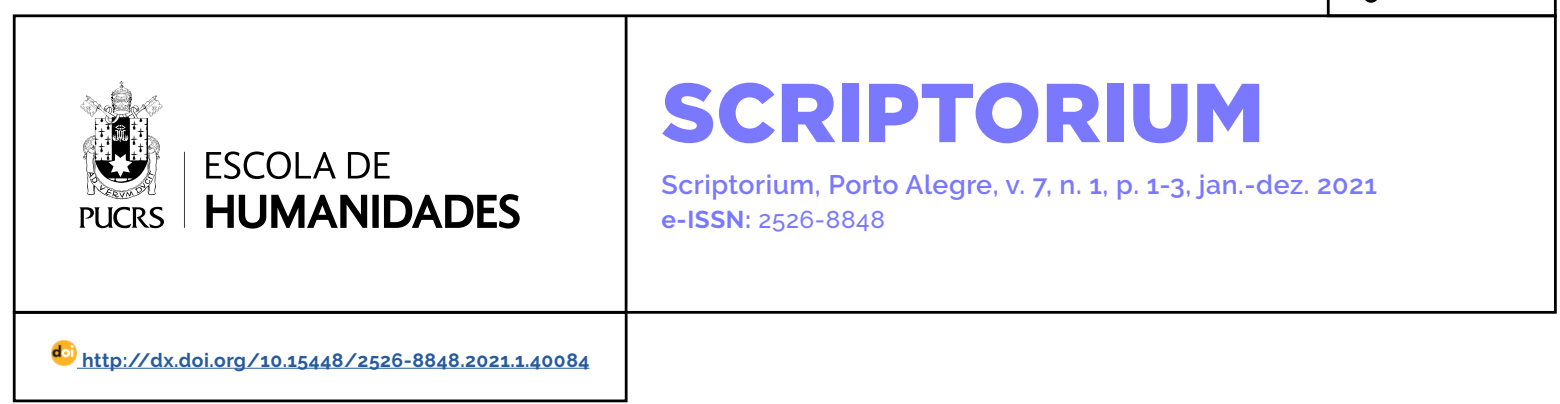

SEÇÃO: PRODUÇÃO LIVRE

\title{
Dancemos o corpo fatigado da lavagem de roupas e da lavagem da língua
}

Let us dance the tired body of washing clothes and washing the tongue

\section{Leda Maria Fonseca}

Bazzo $^{1}$

orcid.org/0000-0002-1152-9490 bazzoleda@gmail.com

Recebido em: 18/11/2020. Aprovado em: 04/11/2021. Publicado em: 28/12/2021.

\section{(c) (i)}

Artigo está licenciado sob forma de uma licença Creative Commons Atribuição 4.0 Internacional.
Aquela coreografia lá eu me lembro... É uma memória-hábito que forma singelos desenhos que mãos molhadas, em um vai e vem, movimentam como em uma pintura, e dedos, em alcance dos finos tecidos, me mostram diferentes movimentos, delicados, que abraçam esses tecidos sobre líquidos do esfregar, enxaguar, torcer, na exalação de aromas. Isso me diz qualquer coisa em uma espécie de incorporação... A lembrança retorna, turva, espirala, ondula e se move repetida vezes... Meus pensamentos se embaralham... Imersa em um transatlântico, uma babel de vozes sendo levadas... Eu posso traduzir as coisas mais óbvias: que meu computador funciona, que meu chuveiro esquenta, que meu fogão acende, que meu lixo é pego por um caminhão, mas eu sei pouco daquela coreografia, então registro... E volto a registrar.

A coreografia retorna, circula, ondula, manifesta-se de novo na minha cabeça, mas eu não sei se posso suportar esse final, descrever e representar o significado guardado, gesto último... Desmaio e o restituo, o replico, no meu corpo... Mas eu não sei se posso sentir bem o signo dessas mãos e elas não me são sem sentido, elas me percebem vendo, descrevendo... Eu não sei se posso representar esse final, o significado guardado. E essas mãos sem máquinas e, ao pensar nelas, meus dedos dançam na máquina, escrevo! As minhas mãos são como armas! Distante de lembrar os tempos da guerra: a roça, o árduo trabalho sob o sol, o arado, a plantação, o boi, a vida do animal, o animal na vida... E a delicadeza inclui todo o drama de trabalho... Muitas coisas, de pequenas coisas que preciso registrar, lembrar, reapresentar...

Eu suponho que vocês possam ver como meus dedos se movimentaram com e sem a máquina, como minhas mãos passearam pelas longas histórias que preciso descrever. Esse fardo sobre minhas costas que comecei igualmente a sofrer, feito todas nós, mulheres, lavadeiras, serpenteando essa terra, esse fogo, essa água e esse ar que impulsiona meus braços a conversarem com esses tecidos e a água. As minhas 
omoplatas se curvam, minha fala e comportamento na expansão desse local, esse barro em transformação, as curvas espiraladas do descer e subir ladeiras, os joelhos em dor como as pernas que passeiam a moverem-se os quadris, que ondulam embaixo e em cima. Os pés, combinados nessa terra, que pisam e vibram sobre esse chão de fogo, como um dragão, feito o rugido de um leão, a tradução dessas vozes, a divulgação dessas narrativas.

Vocês podem averiguar essa fala de lavadeira com as teorias? Como conversei com os autores, como mudei os argumentos, como fui e voltei, como retornei à lavagem, nesse campo, nesse solo santo. Dialoguei com os vivos e os mortos, sobre esse terreno, sendo, com as lavadeiras mais corajosas e combativas, a expressão de como juntas nos sentimos, se temos energia ou se estamos sem vontade. Senti como nossas mãos estão conectadas com nosso cérebro, como nossos desejos se movem sobre nossas bocas em fonemas que se expandem, como agora os olhos almejam o horizonte, nossos sexos, como fêmeas que dilatam, furam a terra e vazam nossos gozos em fonemas por superficies remotas. Percebi como nossos corações esfregam, como nossos narizes farejam pensamentos sobre nossas testas, as frases, como parte do nosso útero, os acentos, as gírias, como a graça do desenho das cores em ressonâncias. Experimentei a felicidade para lavar a espontaneidade, a brincadeira que perfura as peles como um teatro, o cotidiano que me mostra as cenas, as surpresas, os dramas reais e fabricados.

Vocês percebem que vesti e tirei roupas? Vocês percebem que comecei a eliminar as sujeiras das minhas roupas? E com a entrada nesse jogo, nessa atividade, agora, desenvolvi outra astúcia. $E$, ainda assim, vocês querem uma tese objetiva... Necessidade de objetivar. Observe como se escothe o objeto de estudo, perceba como ele entra, se encaixa, como adere, dança, aconchega nossa pele, penetra, perfura. Veja como ele avança nesse imaginário real. Nesses dias mesclam-se as memórias, as histórias, feito a ação do homem. No padecer do tempo, o objeto de estudo cho- rou... um sentimento tão profundo que o soluço saltou ao peito em gritos... Ele protesta, reclama... E depois, após uma pausa, ele começou a cantar uma melodia diferente, insinuante, provocadora. Ele não é tão sério como eu pensava! Ele enreda os sentimentos... Ele tem o poder de hipnotizar e você, que o acha frio, não percebe, mas ele esquenta, aconchega, nina e faz sonhar.

O objeto de estudo se escuta, se demanda, se aproxima, se distancia, se lança ao ataque e embrutece... Transfigura em uma quase morte. Ele desfalece e sonha, mas depois recomeça: levanta cedo, limpa o território, constrói o espaço, se reintroduz, se atualiza. Se estiver sem energia, não pode jogar com as cenas, a plasticidade cerebral demanda atenção, ver o cotidiano e minha penetração nas histórias obscuras desses tecidos, o silêncio dos signos, a palavra oculta, a relação do lavar juntas... Ousei entrar... Praticar estar lá, escrever, perceber a pele... Vejo meu desejo nessa relação, a origem do meu delírio. Fico impressionada nessa brincadeira real... Com esse espetáculo que faço e dinamizo. Posso filmar nosso sangue, ele corre nas frases, nos gestos, no lavar, no passar, no colocar e tirar roupas...

Nada em questão... O gesto explica essa vida... É o meu sangue, esse sangue que escorre na tese por gastar horas nessa tela, feito parte de uma dramaturgia, a movimentar as cenas, pedaços da minha própria vida extorquida... A solitude do lavar roupas, do lavar a língua. Veja como produzi os argumentos, como guardei a memória do gesto, o objetivo... A máquina, os dedos. Vocês sabem o que quero, qualquer coisa da afirmação da minha própria existência, mas muitas vezes não sei o quê, por onde recomeçar, como guardar esse objetivo. Abdicar da vida em favor do trabalho, do outro... Importa quem é esse outro... Vocês me conhecem, agora vocês sabem o que tenho na minha cabeça, mas não sei exatamente o que e como fazer.

A minha vida está por um fio, que a sociedade cruelmente teceu... Todas as pessoas vêm aqui e me dizem qualquer coisa todos os dias... Se apaixonam e nunca mais voltam... Vocês percebem minha pele aqui? Minha veia? Aqui bebo 
esse veneno, esse dia a dia, essa prescrição da lavagem que segui são lembranças obscuras de signos que não me recordo bem, esse imaginário povoado de monstros que sobem e descem pelas paredes e adentram os muros...

É assim que lavo, é assim que escrevo essas muitas línguas, tudo, tudo, sozinha como um teatro de marionetes em que entram e saem pessoas, roupas, cores, cenários... Mas não é teatro, é uma figuração, como em uma arena, um drama, mas qual o texto? Organizei os argumentos e essa dilatação para o fim... Qual o final? A meditação, a atitude desnuda que encontra a noite em dia...

Incomoda-me a ideia desse drama, desse teatro que me aperta, o roteiro, essas cenas perdidas que não consigo captar e traduzir, essa solidão da noite adentro, a meditação, esse jogo, essa narrativa imaginária... Não sei se poderei conquistar esse título, esse direito depois de tanto labutar, depois do outro, gravar o sentido desse drama, perceber o desdobramento político da tese...

Mude um pouco, recomendam vocês, para me fazer sentir no interior da lavadeira, sentir ela, dentro dela, ela com ela, inteira, autêntica. Mudar... Eu assim na casa dela, na vida dela, lavando como ela, criando as coisas dela, sendo ela, vivendo o cotidiano dela...

Se faço tudo isso é para captar essas vidas que estranhamente me tira desse deserto. É por jogar juntas que faço a tese... Nesse romance, eu sou elas, elas são eu, eu as represento, elas me representam. E vocês? Conseguem ser nós? Restarão também vocês sendo elas, vocês sendo eu, elas sendo vocês? Senti-las, esquecer e ser elas, você sou eu, eu sou você, elas somos nós, nós somos a criação juntas...

As representações, o tom dessas horas, as atmosferas, os silêncios, o saber lavar roupas, abandonar as excitações, transmutar, mudar, mudar se puder, mas esqueça o cânone... Não diga nada a ninguém que poderá prescrever outros sentidos desse teatro, dessa dança como trilha sonora de imagens... Como um drama, feito os grandes conflitos das cenas trágicas...

Danço a lavagem aqui, no horizonte. Meus olhos, como sentimentos de todas as minhas faltas, o labor, como um exilio, minhas respirações ditando ritmos frenéticos que golpeiam pulmões arremessados no planeta... Agora, na navegação sobre as águas, meu corpo como ilha no isolamento... O além-mar... A doação, a entrega a esse trabalho. Meu hábito do movimento é como uma dança, como uma parte coreográfica que ensaio dia a dia, registros para um objetivo metafórico transplantado, como manual estético da sociedade, percorrendo desenhos imaginários, como rasante dos pássaros. As mãos estão sobre o teclado da máquina, nesse cenário, nessa lavanderia, nesse escritório coberto de letras, diálogos... As palavras sobem e descem. Mudar as palavras, minha arma, lembrar longe, o combate, explosão de qualquer coisa da minha vida retida!

Eu lembro o corpo... Então, dancemos juntas, dancemos o tempo, o vento oceânico entre o Atlântico. Nesse mar, meu coração é agora pacífico, essas águas em que, juntas, caminhamos distante, esse nado... Essa maré, essa dança sobre tecidos coloridos em que morro. Danço agora o trabalho do corpo fatigado, o sonho, a poesia, dancemos todos...

\section{Leda Maria Fonseca Bazzo}

Doutora pelo Programa de Pós-Graduação em Cultura e Sociedade Pós-Cultura da Universidade Federal da Bahia (UFBA), em Salvador, BA, Brasil; mestre em Saúde Comunitária pelo Instituto de Saúde Coletiva da Universidade Federal da Bahia (ISC/UFBA), em Salvador, BA, Brasil; professora da Universidade Federal da Bahia (UFBA), em Salvador, BA, Brasil.

\section{Endereço para correspondência}

Leda Maria Fonseca Bazzo

Av. Reitor Miguel Calmon, $\mathrm{s} / \mathrm{n}$

Canela, 40231-300

Salvador, BA, Brasil

Os textos deste artigo foram revisados por Poá Comunicação e submetidos para validação do(s) autor(es) antes da publicação. 